\title{
Historical land-use legacy and Cortaderia selloana invasion in the Mediterranean region
}

\author{
ROSER DOMENECH* ${ }^{*} \dagger$, MONTSERRAT VIL $\grave{A}^{*} \dagger$, JOAN PINO*, and JOSEP GESTI \\ ${ }^{*}$ Centre de Recerca Ecològica i Aplicacions Forestals (CREAF), Universitat Autònoma de Barcelona, 08193 Bellaterra, Barcelona, \\ Spain, †Unitat d’Ecologia, Departament de Biologia Animal, Biologia Vegetal i Ecologia, Facultat de Ciències, Universitat \\ Autònoma de Barcelona, 08193 Bellaterra, Barcelona, Spain, †Grup de Recerca de Flora $i$ Vegetació, Universitat de Girona,
} 17071 Girona, Spain

\begin{abstract}
Two major components of global change: land-use changes and intentional or accidental species introduction are threatening the conservation of native species worldwide. In particular, Mediterranean coastal areas are highly susceptible to the invasion of alien species and they also have experienced major changes in land use such as agricultural abandonment and urbanization. However, there has been little research done which quantitatively links biological invasions and the components of land-use changes (i.e. number, trajectory and direction of the changes). We analysed the current distribution and abundance of Cortaderia selloana (Schultes et Schultes fil.) Asch. et Graebner, an alien ornamental species, in 332 fields in Aiguamolls de 1'Empordà (Catalonia, NE Spain) and related the patterns of invasion to spatiotemporal data on land-use changes from 1956 to 2003. Our aim was to determine which land uses had been more susceptible to $C$. selloana invasion during the last 5 years and to find out which components of land-use changes triggered invasion. We found that $22.30 \%$ of the fields are currently invaded. In the last 5 years, fields have triplicated the total density of $C$. selloana. The presence of $C$. selloana decreases with the distance from urban areas. Invasion is over-represented in pastures and old-fields, and it has increased with time since abandonment. The presence of $C$. selloana was also associated to fields that had experienced many changes in land use in the last 46 years. The most heavily invaded fields were those that were pastures in 1956 and are now old fields in 2003. On average, the largest plants are found in agricultural field margins and in fields that had a disturbed land use both in 1956 and in 2003. Furthermore, pastures had the lowest proportion of reproductive plants. Overall, current $C$. selloana patterns of invasion can be explained by the historical legacy of land-use changes.

Keywords: agricultural fields, alien plant, GIS, global change, land-use changes, land-use history, Mediterranean Basin, old-fields, Pampas grass, pastures
\end{abstract}

Received 13 October 2004; revised version received and accepted 9 January 2005

\section{Introduction}

Biodiversity is mainly being threatened by two components of global change: mobility and land-use change. The mixing of the globe's biota because of the breakdown of the global biogeographic barriers (Vitousek, 1994; Mooney \& Hobbs, 2000) is potentially the factor of

Correspondence: Domènech Roser, Centre de Recerca Ecològica i Aplicacions Forestals (CREAF), Universitat Autònoma de Barcelona, 08193 Bellaterra, Barcelona, Spain, tel. + 34935811877 , fax + 349358 14151, e-mail: r.domenech@creaf.uab.es greatest impact on worldwide biodiversity (Sala et al., 2000). Biological invasions are escalating firstly because of, the increasing number of intentional or accidental introductions of alien species caused by biotic change, and secondly, because of land-use changes which provide open windows to the colonization and spread of new arrivals (Vitousek, 1994; Pysek, 1998; Mack \& Lonsdale, 2001).

Changes in land use can be defined as land transformations from one ecosystem 'state' to another in terms of ecosystem structure, composition and function (Hobbs, 2000). Many observational analyses 
have reported that land-use changes increase biological invasions, since the most heavily invaded land-use types are those which directly or indirectly suffer major environmental changes or are 'less natural'. Despite this evidence, there has been little research studying the historical factors, such as previous land uses, that may enhance invasions through their influence on the initial characteristics of a site and through the colonization of the first stages of succession. Therefore, to study how land-use changes interact with invasions and to find out which factors trigger invasions it is necessary to link both phenomena in a spatiotemporal way (Vilà et al., 2003). For example, if within a particular land use there are differences in the distribution or abundance of an alien species, analysis of the spatiotemporal sequence of land-use changes might relate these differences to successional stages or to differences in the parameters (i.e. components) describing land-use changes. Such parameters are the number of different land uses, the trajectory and the direction of the landuse changes which could lead to a final degradation or to a final restoration state.

Land-use changes are paramount in the history of the Mediterranean Basin since its landscape has long been modified by human activities (Naveh \& Vernet, 1991). During the last 10000 years, forest practices, livestock grazing and fire have profoundly changed its landscape (Thornes, 1996). Nowadays, these traditional activities have gradually become nonviable and have resulted in rural depopulation. In addition, there have been many intentional and accidental species introductions in the Mediterranean Basin (Le Floc'h, 1991). Agricultural, ruderal and coastal habitats are commonly invaded by alien plants (Vilà et al., 2001). Specifically, coastal areas are highly susceptible to the invasion of alien species because of their mild climate, the existence of highly disturbed habitats and the human use of alien ornamental plant species which increase the alien propagule pressure (Sobrino et al., 2002). Therefore, Mediterranean areas are excellent study areas to focus on the relationship between land-use changes and patterns of plant invasion.

We studied the link between the distribution, abundance and performance of Cortaderia selloana (Pampas grass), an invasive plant species native to South America, and land-use changes during 1956-2003 in coastal areas of the Parc Natural dels Aiguamolls de $l^{\prime}$ Empordà (Catalonia, NE Spain) in order to test (a) which land uses have been more susceptible to $C$. selloana invasion, (b) which land transformation components trigger invasion, (c) if time since agricultural abandonment increase invasion and finally, (d) if there is an association between the presence of urbanized areas and invasion. We expected old fields to be the most highly invaded type of land use because land abandonment may have created open sites that could have enhanced invasion (Burke \& Grime, 1996; Bastl et al., 1997; Parker \& Reichard, 1998). We also expected that the more changes in land use which have occurred within a field, the more invaded it would be because of more landscape disturbances promoting invasion (Hobbs, 2000; Aragón \& Morales, 2003). Moreover, alien species have been reported to significantly increase along a successional gradient (Rose, 1997) and to decrease as the distance to the potential focus of invasion (e.g. urban areas) increases (Rose, 1997; Roy et al., 1999; Aragón \& Morales, 2003; Vilà et al., 2003).

\section{Material and methods}

\section{Study species}

C. selloana (Pampas grass) is a South American longlived perennial grass native to Argentina, Brazil and Uruguay which is considered invasive worldwide. It was first introduced to Europe between 1775 and 1862 (Bossard et al., 2000). This species has been planted for many purposes (for example, as a windbreak or to prevent erosion), but because of the attractiveness of its panicles it has mainly been used as an ornamental. It has escaped from cultivation and it is invading abandoned farmlands, roadsides, shrublands and wetlands. C. selloana threatens native vegetation and poses a fire hazard because of the accumulation of dry leaves and flowering stalks on the plant (Bossard et al., 2000). C. selloana is gynodioecious (Connor, 1971). This species exhibits a rosette habit and forms a tussock that can reach $2-4 \mathrm{~m}$ in height with long (1-2 m) sharply serrated leaves. It flowers from mid-August to early September, the inflorescences consisting of showy panicles at the end of a stiff stem. Panicles produce copious amounts of small, wind-dispersed seeds $\left(10^{6}\right.$ seeds per mature plant for females and $10^{5}$ for hermaphrodites; Connor \& Edgar, 1974; Lambrinos, 2002). Seedlings establish in spring, require sandy soils, moisture and light. The grass tolerates a wide range of environmental conditions such as winter frost, intense sunlight, warm summer temperatures and moderate drought (Bossard et al., 2000).

\section{Study site}

The study site was located in La Rubina (UTM quadrat 31 T EG17), a protected wetland area of the Parc Natural dels Aiguamolls de l'Empordà (Catalonia, NE Spain). The climate is Mediterranean with mild, wet winters and hot dry summers. Mean monthly temperatures for the coldest (January) and the hottest (August) months are 
10.3 and $26.3^{\circ} \mathrm{C}$, respectively. The mean annual precipitation is $739.4 \mathrm{~mm}$ (Clavero et al., 1996, http:/ / www.meteocat.com). Soil comprises silt and clay, occasionally mixed with sand.

La Rubina is an agricultural zone of private ownership within the protected wetland. Land division is quite regular as a result of Mendizabal's disentitlement that took place in the 19th century. Consequently, the area is mainly formed of small uniform sized fields ( $15 \mathrm{~m} \times 160 \mathrm{~m}$ approximately, $2400 \mathrm{~m}^{2}$ ) surrounded by $2 \mathrm{~m}$ wide water channels bordered by Tamarix spp., Salix spp. and Phragmites australis as dominant species. The majority of the fields are crops of forage herbs and grasses such as lucerne (Medicago sativa) and barley (Avena sativa). Pastures, which mainly consist of grasslands with Festuca arundinacea, Elymus pungens, Trifolium pratense, and halophytic communities dominated by Juncus acutus, are the second most abundant land uses. However, land abandonment has increased during the last decades. In addition, this area has experienced important changes since 1956 because of the launching of mass tourism which has been characterized by an increase in housing development and the rapid appearance of tourist resorts (1956 is the first year from which historical data is available). Currently, the study fields are surrounded by highly urbanized areas (i.e. campsites and resorts) in which C. selloana has been planted as an ornamental.

\section{Surveys of fields invaded by C. selloana}

Detailed surveys among 332 fields of La Rubina were conducted in the summer of 1998, and 2003. In 1998, all C. selloana plants found within each invaded field were counted. In 2003, we also counted all C. selloana plants in fields where less than 50 individuals were found. If more than 50 individuals were found within a field, three randomly placed $15 \mathrm{~m} \times 15 \mathrm{~m}$ plots were established and all the individuals within plots were surveyed. In the 2003 survey, the height and two perpendicular plant diameters at the base of plants were measured for all C. selloana plants counted. To estimate aboveground biomass we approximated the shape of $C$. selloana to a part of a semisphere $(V)$ whose formula is $V=2 / 3 \pi R^{2} H$, where ' $R$ ' is the mean species radius which was estimated with the two perpendicular diameters and ' $H$ ' its height. In addition, we also noted if the plants were reproductive by the presence of flowering panicles.

Therefore, for 2003 we have several components of invasibility for each field: the probability for C. selloana to established itself (the frequency of invaded fields), total plant density, density of flowering plants, mean plant biomass and reproductive individuals/total individuals ratio (hereafter referred to as RI/TI) for each field.

We compared C. selloana density between 1998 and 2003 with a Wilcoxon's Signed Rank Test as C. selloana total density did not follow a normal distribution neither in 1998 nor in 2003. We made a simple regression with the density from 1998 and 2003 to test if the slope of the regression was significantly different from 1 , and to find out if the invasion of $C$. selloana had increased or decreased during this period of time. In addition, we analysed the invasion patterns graphically with log-transformed data (density +1 ) because most plant densities were low or zero either in 1998 or in 2003.

\section{Land-use/history analysis}

Land uses of the 332 fields and surrounding area of La Rubina were determined through the examination of aerial photographs $(1: 22000$ and $1: 18000)$ and orthophoto maps (1:5000) from the years 1956, 1970, 1987, 1996 and 2002. For each year, fields were classified in five land-use categories: (1) agricultural, (2) pasture, (3) old field, (4) urban development (i.e. with buildings) and (5) unknown. The last category refers to the cases in which we could not determine clearly their status because of the low quality of the images. Land-use classification was done according to the brightness of the colour of the fields and to the presence or absence of clear margins after field checking.

We classified each field according to the following components of land-use history: (1) land-use changes during 1956-2002 (considering 0 and 1-or-more changes), (2) trajectory of the land-use change (comparing land use at the beginning and at the end of the time series) and (3) direction of the land-use change considering pastures and old fields as semi-natural and agricultural or urban developed land uses as disturbed. For example, a field that has gone through the following sequence: old field (1956)-pasture (1970)pasture (1984)-agricultural (1996)-agricultural (2002), has undergone more than one land-use change, it has been altered from an old field land use (1956) to a agricultural land use (2002) and it has changed from semi-natural land use to disturbed.

\section{Linking distance to urban areas to C. selloana invasion}

We analysed the association between the percentage of invaded fields in 2003 and the distance to urban areas. Urban settlements of the study area were digitised and converted into raster format; with a pixel of $1 \mathrm{~m}$. Maps of distance to each pixel in the study area to the nearest urban pixel were then obtained using MiraMon, an 
in-house developed GIS (Pons, 2001). The mean distance of each field to urban areas was obtained by combining the distance map and a polygon layer with the field boundaries, and by calculating the mean value of pixels of the distance map falling into each field. We tested if there was a relationship between the distance to urban areas and both the presence and total density of $C$. selloana per field by a logistic regression and the Spearman's rank correlation test, respectively.

\section{Linking land uses of 1998 and 2003 to C. selloana invasion}

We tested if C. selloana invasion in each land use was not biased towards the most abundant land use by matching field surveys of 1998 and 2003 with their most contemporary land-use maps (1996 and 2002, respectively). We compared, then, the observed frequency of invaded fields per land use with their expected frequency according to the relative proportion of land uses by means of a $\chi^{2}$ goodness-of-fit analysis (Vilà et al., 2003). Total plant density in 1998 and 2003, density of flowering plants, mean plant biomass and RI/TI per field in 2003 were also tested among land uses with ANOVA tests, or with Kruskall-Wallis analysis when data did not follow a normal distribution. The Scheffé test was used to analyse pair-wise differences.

\section{Linking land-use history (1956-2003) to C. selloana invasion}

Likewise for land uses, we compared each land-use history component defined between 1956 and 2003, to determine if the observed number of invaded fields within each category of land-use history was significantly different from its relative frequency by a $\chi^{2}$ goodness-of-fit analysis.

Differences in C. selloana total density, density of reproductive plants, mean plant biomass and RI/TI between the number of land-use changes were compared by a $t$-test or a Mann-Withney $U$-test. Differences in trajectory and direction of the land-use change were compared with an ANOVA, or alternatively with a Kruskal-Wallis test when data were not normally distributed.

Furthermore, an ANOVA was used to test the differences in C. selloana density among a successional series according to the abandonment age of each invaded field, classified as follows: (1) still agricultural, (2) abandoned during the last 7-16 years and (3) abandoned during the last 33-46 years.

For those components of land-use changes which were significant on a certain invasibility component, we tested if significance was not affected by time since abandonment and the distance to urban areas by a general linear model (GLM) analysis, with invasibility components as dependent variables and components of land-use changes, distance to urban areas and time since abandonment as independent variables. Unfortunately, we could not include all land-use change components in the analysis and identify interactions because of unbalanced data and small sample size. Moreover, a previous contingency table analysis detected strong correlations between land-use history components.

\section{Results}

Patterns of C. selloana invasion

The percentage of invaded fields increased 1.85 times during 5 years (from $12.05 \%$ in 1998 to $22.30 \%$ in 2003), at a mean rate of 0.37 fields per year. On average, total plant density was significantly higher in 2003 than in 1998 ( $Z$-value $=5.07, P<0.001$ ). Comparing all the fields that had been invaded once, either in 1998 or in 2003 , the mean total density of $C$. selloana changed from $31.86 \pm 12.51$ in 1998 to $91.62 \pm 27.01$ individuals ha ${ }^{-1}$ in 2003, approximately a threefold increase during the study period.

As regards C. selloana total density, there has been a definite increase from 1998 to 2003 since the majority of points are situated above the diagonal line whose equation $(Y=X)$ represents no increase in density (Fig. 1). There is a significant simple linear correlation between invasion in 1998 and invasion in $2003(Y=$ $\left.43.88+1.50 X, R^{2}=0.5 ; F_{1,80}=74.35, P<0.0001\right)$ and the slope of the line of best fit is significantly different from $1\left(t_{79}=2.87, P=0.003\right)$. There were 42 fields without $C$. selloana in 1998 which were invaded in 2003. There were also eight fields invaded in 1998 that were not invaded in 2002. The instances of decrease in C. selloana total density are probably because of human elimination of the plant.

\section{Invasion and distance to urban areas}

The presence/absence of C. selloana in the fields of La Rubina varied significantly with the distance from urban areas $\left(\chi^{2}=19.31, P<0.0001\right)$. The number of invaded fields decreased as the distance from urban areas increased. The majority of the invaded fields were located less than $200 \mathrm{~m}$ from urban areas (Fig. 2). However, there was no significant relationship between C. selloana total density and the distance from urban areas (Spearman's correlation coefficient $r=0.034$, $P=0.77)$. 


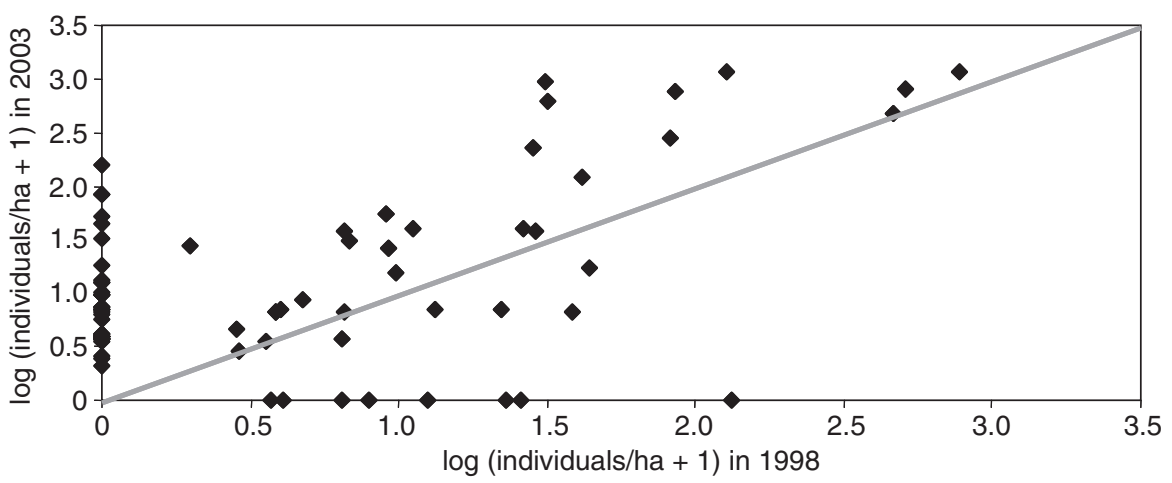

Fig. 1 Cortaderia selloana invasion patterns between 1998 and 2003. The diagonal line represents no increase in density.

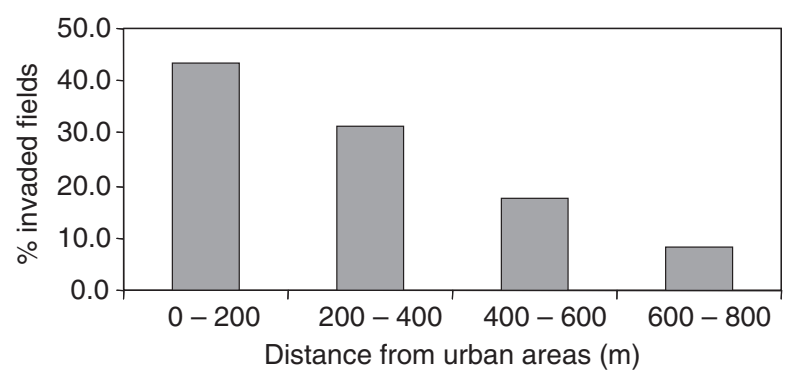

Fig. 2 Relationship between the percentage of invaded fields and the distance from urban areas.

\section{Linking land uses with C. selloana invasion}

From 1956 to 1987, pastures were the most important land use (>60\%) (Fig. 3a). In 1996, the percentage decreased considerably to $26.5 \%$ and since then it has not varied. In contrast, the percentage of agricultural fields has changed from $19.0 \%$ in 1987 to $66 \%$ in 1996. The percentage of old fields has increased steadily with time but it has always been smaller compared with pastures and agricultural fields. The appearance of buildings has also slightly increased from $0 \%$ in 1956 to $0.6 \%$ in 2002. The percentage of nonclassified fields (unknown) has decreased through time because of better resolution of the images (Fig. 3a).

Focussing on 1996 and 2002, the most invaded land uses were old fields followed by pastures. The percentage of invaded agricultural fields, pastures and old fields has increased 2.3, 1.5 and 1.5 times, respectively (Fig. 3b). Furthermore, during this short period of time, C. selloana density has increased in pastures and old fields, these being more highly invaded than agricultural fields (Fig. 3c).

The analysis of the association between C. selloana invasion and land use demonstrates that this distribution is not random (Table 1). Observed and expected distributions of $C$. selloana invasion were significantly different both in 1998 and in $2003\left(\chi^{2}\right.$-test $=11.64, \mathrm{df}=2$, $P=0.003$ and $\chi^{2}$-test $=6.84, \mathrm{df}=2, P=0.03$, respec- tively). C. selloana invasion in pastures and old fields were over-represented for both years, whereas, in agricultural fields it was under-represented.

The C. selloana total density was significantly different between the three land-use types both in 1998 and in $2003\left(F_{2,37}=3.52 ; P=0.04\right.$ and $F_{2,47}=6.26 ; P=0.004$, respectively) (Fig. 3c). In 1998 pastures were the most invaded land use $\left(122.3 \pm 52.1\right.$ individuals $\left.\mathrm{ha}^{-1}\right)$ followed by old fields $\left(27.0 \pm 24.7\right.$ individuals ha $\left.{ }^{-1}\right)$ and agricultural fields $\left(16.3 \pm 3.4\right.$ individuals ha $\left.{ }^{-1}\right)$. By contrast, in 2003 the mean C. selloana total density was higher in old fields $\left(242.2 \pm 228.5\right.$ individuals ha $\left.^{-1}\right)$ followed by pastures (204.2 \pm 84.8 individuals ha $\left.{ }^{-1}\right)$. Agricultural fields were the least invaded land-use type $\left(15.9 \pm 4.4\right.$ individuals $\left.\mathrm{ha}^{-1}\right)$. Mean total density of reproductive plants in 2003 did not significantly differ between land uses $(H=2.3 ; \mathrm{df}=2 ; P=0.32)$.

In 2003, C. selloana biomass was significantly different among land uses $\left(F_{2,724}=19.8 ; P<0.0001\right)$. Plants in agricultural fields were larger than in pastures and old fields. No significant differences were found between plant biomass of pastures and old fields (Schefe test, $P=0.6$ ). The biomass distribution of $C$. selloana in pastures (Fig. 4b) and old fields (Fig. 4c) was a reversed-J shape, with more than $50 \%$ of individuals concentrated in the first volume category $\left(0-5 \mathrm{~m}^{3}\right)$. However, in agricultural fields (Fig. 4a), the biomass distribution was less skewed. For all land uses the biggest individuals were all mature. However, in old fields plants with less biomass had a higher fertility than in the other two land uses. There were significant differences in RI/TI between land uses $(H=6.74 ; \mathrm{df}=2 ; P=0.03): \mathrm{RI} / \mathrm{TI}$ was higher in old field and agricultural fields $(0.93 \pm 0.49$ and $0.91 \pm 0.36$, respectively) than in pastures $(0.67 \pm 0.91)$.

Linking land-use changes history with C. selloana invasion

C. selloana total density increased significantly along succession $\left(F_{2,71}=3.76, P=0.03\right)$. Fields that were 

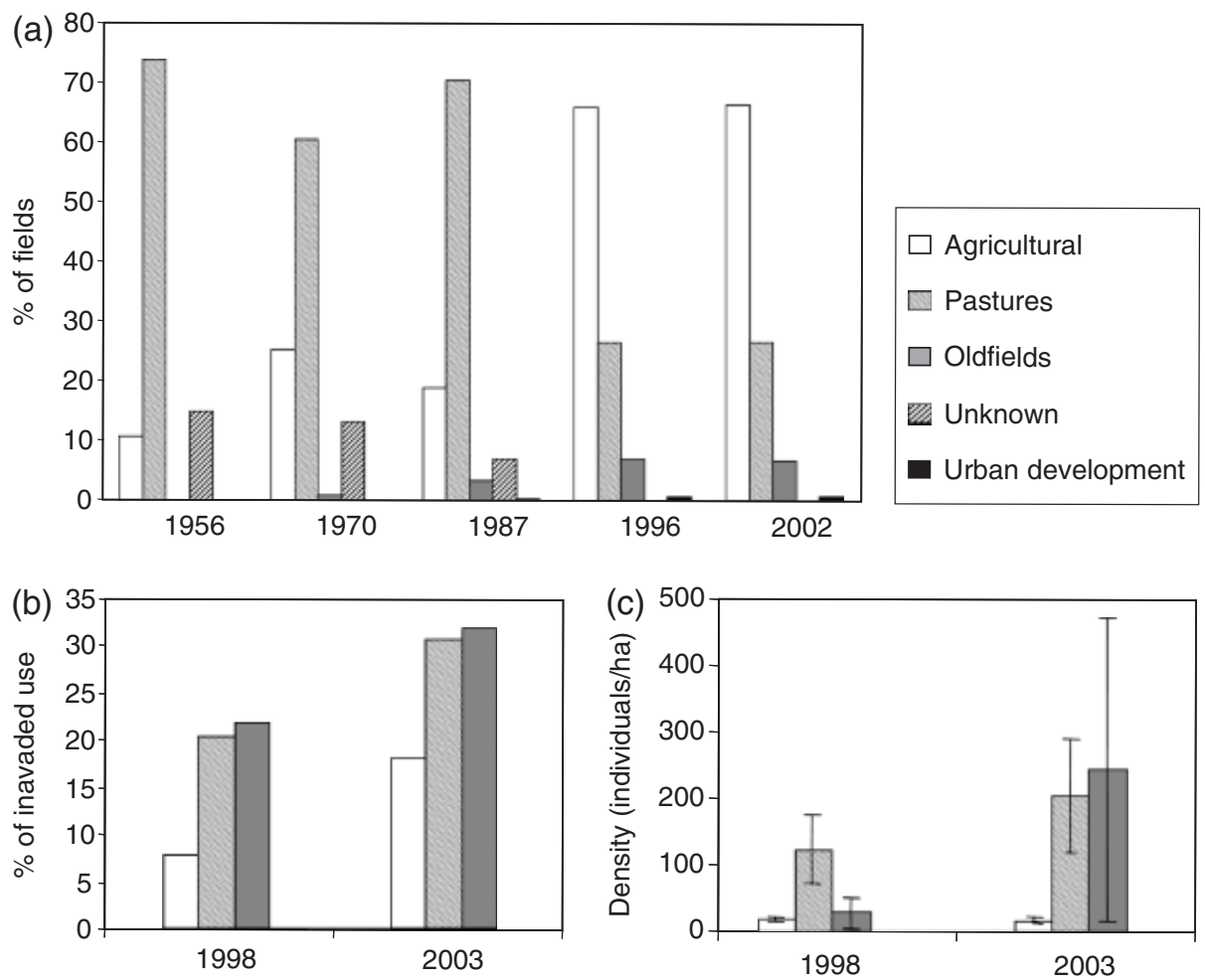

Fig. 3 (a) Land uses in 1956, 1970, 1987, 1996 and 2002. (b) Percentage of Cortaderia selloana invading land uses in 1998 and 2002. (c) C. selloana density per land use in 1998 and 2002.

Table 1 Observed and expected numbers of invaded and noninvaded fields for the three invaded land uses for the years 1998 and 2003

\begin{tabular}{|c|c|c|c|c|}
\hline \multirow[b]{2}{*}{ Land use } & \multicolumn{2}{|c|}{ Observed } & \multicolumn{2}{|l|}{ Expected } \\
\hline & Invaded & Noninvaded & Invaded & Noninvaded \\
\hline \multicolumn{5}{|l|}{1998} \\
\hline Agricultural & 17 & 202 & 26.5 & 192.4 \\
\hline Pastures & 18 & 70 & 10.7 & 77.3 \\
\hline Old fields & 5 & 18 & 2.8 & 20.2 \\
\hline \multicolumn{5}{|l|}{2003} \\
\hline Agricultural & 40 & 180 & 49.3 & 170.7 \\
\hline Pastures & 27 & 61 & 19.7 & 68.3 \\
\hline Old fields & 7 & 15 & 4.9 & 17.1 \\
\hline
\end{tabular}

abandoned at least 33 years ago were the most dense $\left(210.1 \pm 85.1\right.$ individuals $\left.\mathrm{ha}^{-1}\right)$, followed by fields that were abandoned from 7 to 16 years ago $(63.1 \pm 43.1$ individuals $\mathrm{ha}^{-1}$ ). Fields that have not been abandoned were the least invaded $\left(13.4 \pm 3.5\right.$ individuals $\left.\mathrm{ha}^{-1}\right)$. However, fields that were abandoned from 7 to 16 years ago were the most invaded $(44.44 \%)$, followed by fields that were abandoned from 33 to 47 years ago $(31.71 \%)$. Again, fields that had not been abandoned were the least invaded $(18.35 \%)$.
The $\chi^{2}$-test confirms that there was a significant association between the presence of $C$. selloana and land-use changes during 1956-2002 $\left(\chi^{2}=12.50, \mathrm{df}=1\right.$, $P=0.0004$ ). Invaded fields that have suffered one or more land-use changes were over-represented (16.17\%) whereas fields that remained stable (with no land-use changes) during this period of time were underrepresented $(9.36 \%)$. However, neither the trajectory of the land-use change nor the direction of the land use were associated with C. selloana invasion $\left(\chi^{2}=3.97\right.$, $\mathrm{df}=6, P=0.68$ and $\chi^{2}=2.76, \mathrm{df}=3, P=0.43$, respectively) (Table 2).

The preliminary approach revealed that $C$. selloana total density did not differ significantly with land-use changes $\left(t_{43}=1.10 ; P=0.28\right)$. Conversely, it significantly depended on the trajectory of the land-use change $\left(F_{4,40}=3.47 ; P=0.02\right)$. Fields that have changed from pastures to old fields and fields that have remained as pastures were the most highly invaded. Significant differences in C. selloana total density also appeared related to the direction of the land-use change $\left(F_{3,41}=4.72 ; P=0.006\right)$. Fields that have remained as semi-natural were the most invaded (Table 3 ).

The density of reproductive individuals did not differ significantly among any of the components of land-use history $(Z=0.22 ; P=0.83$ for the number of 

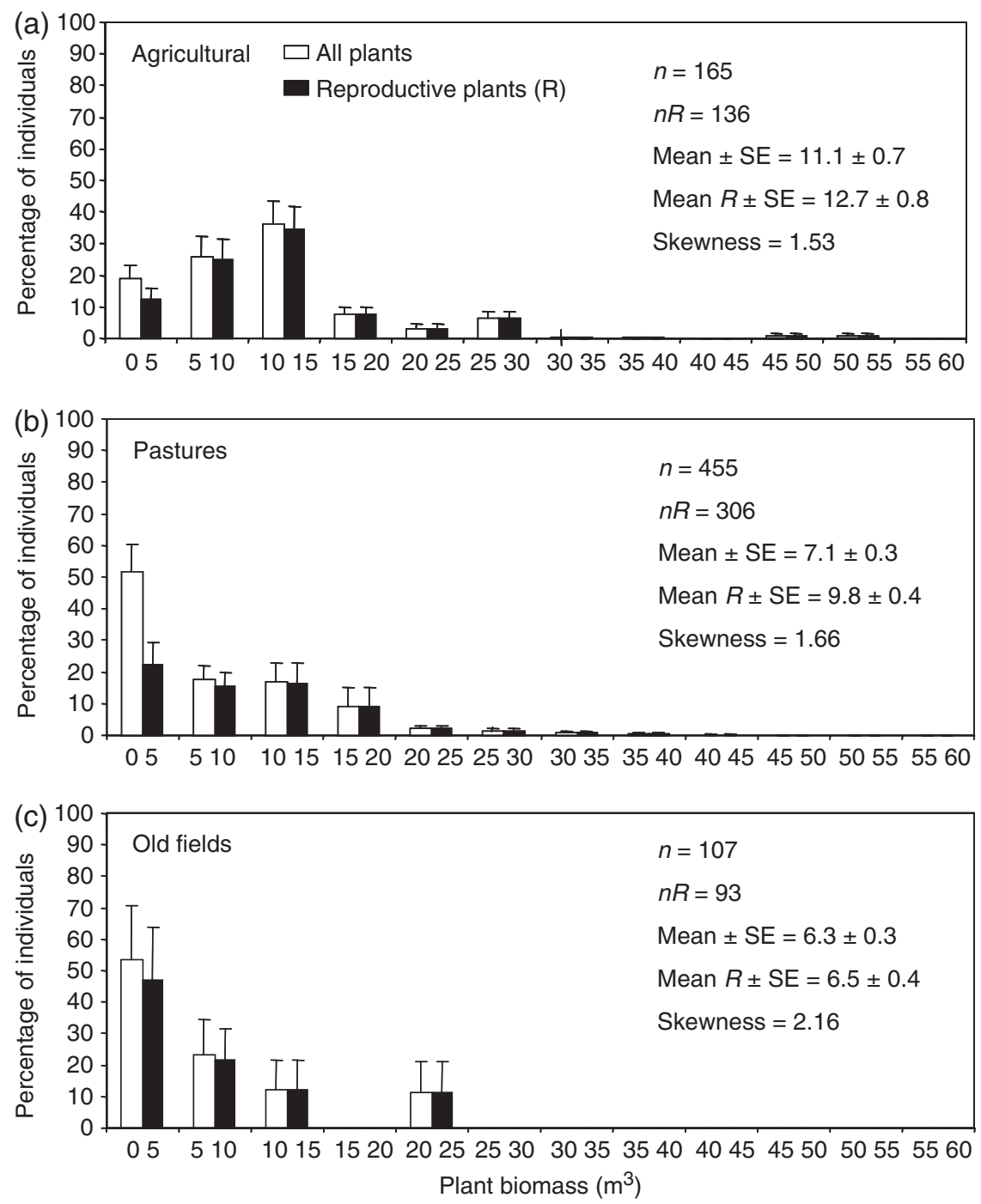

Fig. 4 Size distribution of Cortaderia selloana for the different invaded land uses.

land use changes, $H=3.48 ; \mathrm{df}=4 ; P=0.48$ for the trajectory of the land-use change and $H=3.15$; $\mathrm{df}=3$; $P=0.37$ for the direction of the land-use change). Mean C. selloana biomass did not vary significantly between land-use changes $\left(t_{43}=0.30 ; P=0.76\right)$. Conversely, significant differences appeared considering the trajectory of the land-use change $\left(F_{4,40}=5.07 ; P=0.002\right)$ and the direction of the land-use change $\left(F_{3,41}=6.50\right.$; $P=0.001)$. Mean plant biomass was higher in fields that were agricultural both in 1956 and in $2003\left(21.3 \pm 9.4 \mathrm{~m}^{3}\right)$ and in fields whose direction of the land-use change consisted in having a disturbed land use both in 1956 and in $2003\left(21.3 \pm 9.4 \mathrm{~m}^{3}\right)$. No significant differences in RI/TI appeared considering the number of landuse changes $(Z=1.63 ; P=0.10)$, the trajectory of the land-use change $(H=7.20 ; \mathrm{df}=4 ; P=0.13)$ nor the direction of the land-use change $(H=6.70 ; \mathrm{df}=3$; $P=0.08$, Table 3).
The contingency table analysis on land-use change components revealed that the trajectory and direction of land-use changes were strongly correlated $\left(\chi^{2}=135.00\right.$; $\mathrm{df}=12 ; P<0.0001)$. Therefore, we only considered the trajectory of land-use changes as the explanatory variable and determined the effect of this land-use component, distance to urban areas and time since abandonment on C. selloana density and plant biomass. The GLM revealed that the trajectory of land-use changes was the only independent parameter that had a significant effect on $C$. selloana total density $\left(F_{3,37}=\right.$ 3.30; $P=0.03$ ). Specifically, it explained $35.0 \%$ of the variation. By contrast, $C$. selloana total density did not depend either on the time since abandonment $\left(F_{2,37}=\right.$ $1.93 ; P=0.16)$ or on the distance to urban areas $\left(F_{1,37}=\right.$ $0.13 ; P=0.72$ ). Similarly, $42.5 \%$ of the variation in plant biomass was significantly explained by the trajectory of land-use changes $\left(F_{3,37}=5.05 ; P=0.005\right)$ while time 
Table 2 Observed and expected numbers of invaded and noninvaded fields among the four components of land-use history

\begin{tabular}{|c|c|c|c|c|}
\hline \multirow[b]{2}{*}{ Land-use component } & \multicolumn{2}{|l|}{ Observed } & \multicolumn{2}{|l|}{ Expected } \\
\hline & Invaded & Noninvaded & Invaded & Noninvaded \\
\hline \multicolumn{5}{|l|}{ Land-use changes } \\
\hline 0 & 22 & 110 & 33.7 & 98.3 \\
\hline$\geq 1$ & 38 & 65 & 26.3 & 76.7 \\
\hline \multicolumn{5}{|l|}{ Trajectory of the land-use change } \\
\hline Pasture $\rightarrow$ agricultural & 31 & 93 & 31.7 & 92.3 \\
\hline Pasture $\rightarrow$ pasture & 21 & 50 & 18.1 & 52.9 \\
\hline Pasture $\rightarrow$ old field & 4 & 7 & 2.8 & 8.2 \\
\hline Pasture $\rightarrow$ urban development & 0 & 19 & 0.5 & 1.5 \\
\hline Agricultural $\rightarrow$ old field & 0 & 2 & 0.3 & 0.7 \\
\hline Agricultural $\rightarrow$ agricultural & 3 & 3 & 5.6 & 16.4 \\
\hline Agricultural $\rightarrow$ pasture & 1 & 1 & 1.0 & 3.0 \\
\hline \multicolumn{5}{|l|}{ Direction of the land-use change } \\
\hline Disturbed $\rightarrow$ semi-natural & 1 & 4 & 1.3 & 3.7 \\
\hline Semi-natural $\rightarrow$ semi-natural & 24 & 55 & 20.1 & 58.9 \\
\hline Semi-natural $\rightarrow$ disturbed & 31 & 95 & 32.0 & 94.0 \\
\hline Disturbed $\rightarrow$ disturbed & 3 & 19 & 5.6 & 16.4 \\
\hline
\end{tabular}

Table 3 Cortaderia selloana density, density of reproductive individuals, plant volume and RI/TI for each component of land-use history

\begin{tabular}{|c|c|c|c|c|}
\hline Components of land-use & Density (ind/ha) & DRI (ind/ha) & Volume $\left(\mathrm{m}^{3}\right)$ & RI/TI \\
\hline \multicolumn{5}{|l|}{ Land-use changes } \\
\hline 0 & $132.1 \pm 80.5$ & $31.9 \pm 12.2$ & $9.8 \pm 2.1$ & $0.71 \pm 0.11$ \\
\hline$\geq 1$ & $73.6 \pm 41.0$ & $14.9 \pm 3.1$ & $10.3 \pm 0.7$ & $0.88 \pm 0.04$ \\
\hline \multicolumn{5}{|l|}{ Trajectory of land-use change } \\
\hline Pasture $\rightarrow$ agricultural & $16.9 \pm 4.6$ & $13.7 \pm 3.4$ & $11.1 \pm 0.6$ & $0.91 \pm 0.04$ \\
\hline Pasture $\rightarrow$ pasture & $178.7 \pm 86.0$ & $35.2 \pm 11.9$ & $8.1 \pm 1.5$ & $0.65 \pm 0.11$ \\
\hline Pasture $\rightarrow$ old field & $579.0 \pm 576.5$ & $18.9 \pm 16.3$ & $4.9 \pm 1.4$ & $0.93 \pm 0.07$ \\
\hline Agricultural $\rightarrow$ agricultural & $2.6 \pm 1.1$ & $2.6 \pm 1.1$ & $21.3 \pm 9.4$ & $1.00 \pm 0.00$ \\
\hline Agricultural $\rightarrow$ pasture & $24.7^{*}$ & $16.5^{*}$ & $3.8^{*}$ & $0.67^{*}$ \\
\hline \multicolumn{5}{|l|}{ Direction of land-use change } \\
\hline Disturbed $\rightarrow$ semi-natural & $24.7^{*}$ & $16.5^{*}$ & $3.8^{*}$ & $0.67^{*}$ \\
\hline Semi-natural $\rightarrow$ semi-natural & $228.8 \pm 97.7$ & $33.2 \pm 10.5$ & $7.7 \pm 1.3$ & $0.69 \pm 0.10$ \\
\hline Semi-natural $\rightarrow$ disturbed & $16.9 \pm 4.6$ & $13.7 \pm 3.4$ & $11.1 \pm 0.6$ & $0.91 \pm 0.04$ \\
\hline Disturbed $\rightarrow$ disturbed & $2.6 \pm 1.1$ & $2.6 \pm 1.1$ & $21.3 \pm 9.4$ & $1.00 \pm 0.00$ \\
\hline
\end{tabular}

Values are mean \pm SE.

*Standard error could not be calculated since in these categories there was only one field.

DRI, density of reproductive individuals; RI/TI, reproductive individuals/total individuals ratio; ind/ha, individuals per hectare.

since abandonment and the distance to urban areas had no significant effect on plant biomass $\left(F_{2,37}=2.74\right.$; $P=0.08$ and $F_{1,37}=0.001 ; P=0.97$, respectively).

\section{Discussion}

Some species when introduced into a new area tend to spread from their initial focus of introduction. This process is mainly characterized by an increase in population numbers caused by changes in demographic rates and a simultaneous increase in the area occupied by the population because of the dispersal of propagules (Parker \& Reichard, 1998). The high increase in the percentage of invaded fields and the increase in C. selloana density that has taken place between 1998 and 2003 reflects that the species is expanding fast despite the fact that landowners may have tried to deter its spread. Such management practices have not counterbalanced the constant influx of propagules arriving from nearby tourist resorts that have proliferated since the late 1960s (Saurí et al., 2000). 
Many studies have found that the number of alien species decreases as the distance from the potential focus of invasion increases (Rose, 1997; Aragón \& Morales, 2003; Vilà et al., 2003). Moreover, it is also known that urban areas can be regarded as potential focuses of invasion because of their high richness of alien species (Roy et al., 1999). Our results show that C. selloana presence decreases as the distance from urban areas increases which is also in accordance with patterns of invasion of Opuntia maxima and Pittosporum undulatum. The former is an ornamental alien species also invading coastal areas located less than $200 \mathrm{~m}$ from urban settlements (Vilà et al., 2003). The latter is an Australian native species that is invading bushland areas of northern Sydney and whose density in young (12-13 years) and middle-aged (26-50 years) sites decreases with distance to urban and suburban edges (Rose, 1997). However, its density does not depend on the distance from urban areas. This suggests that while the presence of the first propagules to a site depends on the focus of invasion, population growth depends on local site characteristics.

C. selloana populations in pastures and old fields are not evenly distributed in size since more than $50 \%$ of their individuals are situated in the smallest biomass class and bigger individuals are far less abundant. In contrast, agricultural fields are less invaded, plants are on average larger, small individuals are no longer the most abundant biomass class and population distribution is not as skewed to the right as in pastures and old fields. The different biomass distribution in agricultural fields may be caused by the environmental conditions of field margins where C. selloana invasion is restricted since agricultural margins are unmanaged areas. Except in pastures, most individuals are mature, indicating that invasion in pastures is at a more initial stage than that occurring in old fields or agricultural fields.

La Rubina has experienced a major land-use change from 1956 to 2003. From 1956 to 1987 agriculture was a secondary land-use. This was probably caused by the fact that as in other Mediterranean regions traditional agriculture became progressively economically unviable during the 1960s (Debussche et al., 1999; Grove \& Rackham, 2001). After 1987, most fields shifted from pastures to modern agricultural lands and since 1996 this has been the most abundant land use. Land uses practically have not changed during the period 19962002. C. selloana invasion was not biased towards the most abundant land-use neither in 1996 nor in 2002 although field margins where C. selloana invasion is restricted are more likely to be invaded because of their ruderal characteristics. Moreover, agricultural fields are not the most successfully invaded land use (C. selloana density has not changed during these years). Old fields and pastures have been the most successfully invaded land uses: C. selloana total density in the former has experienced a ninefold increase during the last 5 years and in the latter pastures a nearly twofold increase.

Several techniques have been developed for modelling species distribution and occurrence at regional scales in spatially explicit contexts. A logistic regression model has explored the importance of environmental factors in explaining the current distribution and the future spread of species that are invading the Cape Pensinsula. In particular, elevation and rainfall have been predicted to be the most important factors for determining the frequency of the invasive species Acacia Cyclops and Pinus pinaster. The modelling of their spread has revealed that their distribution will increase significantly, covering a large area of the Cape Peninsula (Higgins et al., 1999). Another study modelled the interactions between environment, plant traits and disturbances of pine invasions in the southern hemisphere. Results showed that all these determinants of invasion success significantly influenced the rate of invasion of pine trees (Higgins \& Richardson, 1998). However, none of these models considered that the current distribution of invasive species can also reflect land-use legacy. We have found that land-use changes trigger the invasion of $C$. selloana. Changes in land use are usually associated to landscape disturbances that may represent an open window to the invasion of alien species (Hobbs, 2000; Aragón \& Morales, 2003), yet the majority of studies analyse land-use changes from a static point of view (but see Vilà et al., 2003). These results are consistent with those obtained for Opuntia stricta and O. maxima distribution in Cap de Creus (NE Spain) where they have invaded the habitats that had experienced more changes during a 20-year period.

The trajectory of land-use change influenced invasion even when time since abandonment and distance to urban areas were included in the model, reinforcing the role of land-use history on invasion. C. selloana total density was higher in fields that were pastures in 1956 and old fields in 2002. This high proliferation of $C$. selloana may be caused by the fact that pastures and old fields are stable environments since they have not been cultivated at least since 1956. Consequently, the longer a field is abandoned, the more C. selloana total density increases.

Our analysis of the land-use history of La Rubina has revealed that between the years 1956 and 2002 some of the agricultural fields have become pastures and old fields. Abandonment of these agricultural fields may have provided an open window to the invasion of C. selloana. In addition, it is known that this species produces a large amount of seeds (Connor \& Edgar, 1974; Lambrinos, 2002) which could take advantage of land abandonment. Consequently, this species could have successfully established itself in these fields and 
increased its density through time. Our results show that fields that have been abandoned for a long time are much more invaded than fields that have been recently abandoned. This is also consistent for the invasion of $P$. undulatum into urban bushland areas (northern Sydney) since the abundance and basal area of this species increases significantly along a successional gradient (Rose, 1997). However, time since abandonment had no significant effect on C. selloana total density when we considered this variable together with the distance from urban areas and the trajectory of land-use changes.

Finally, the direction of the land use also influenced the performance of $C$. selloana. Plants were bigger in fields that had been disturbed since 1956. This occurred particularly in agricultural fields, since their margins offer the invader special conditions which promote growth. In addition, our results suggested that these results were not influenced by the distance from urban areas and time since abandonment.

Land-use history and time since abandonment have been proved of major importance in determining the species composition of a particular area (Aragón \& Morales, 2003). In addition, land-use changes have been tightly linked to biological invasions through alterations in ecosystem dynamics that provide opportunities for species colonization and population expansion D'Antonio \& Vitousek, 1992; Hobbs, 2000). However, it has been reported that there is little research which links both phenomena in a spatiotemporally explicit way (Thomson et al., 1993). Our study is not only useful to describe the present distribution of an invasive species but also to test if differences in its present distribution are because of past land-use changes and if differences within a particular land use can be linked to different successional stages. We have shown that invasion is not biased towards the most abundant land use and that land-use legacy has a strong influence on invasion patterns.

\section{Acknowledgements}

We thank the Aiguamolls de l'Empordà Natural Park and especially to S. Romero for providing the invasion data from 1998. J. Pausas and F. Lloret for their advice throughout the project; J. Companys and M. Romano for field assistance and two anonymous reviewers for comments on an earlier draft. Funding for conducting the field survey was provided by the REN2000-0361/GLO project from the Ministerio de Ciencia y Tecnología and the VI Framework Programme European project ALARM (contract 506675).

\section{References}

Aragón R, Morales JM (2003) Species composition and invasion in NW Argentinian secondary forests: effects of land-use history, environment and landscape. Journal of Vegetation Science, 14, 195-204.

Bastl M, Kocar P, Prach K et al. (1997) The effect of successional age and disturbance on the establishment of alien plants in man-made sites: an experimental approach. In: Plant Invasions: Studies from North America and Europe (eds Brock JH, Wade M, Pysek P, Green D), pp. 191-201. Backhuys Publishers, The Netherlands.

Bossard CC, Randall JM, Hshousky MC (2000) Invasive plants of California's Wildlands. University of California, Berkeley, Los Angeles.

Burke MJW, Grime JP (1996) An experimental study of plant community invasibility. Ecology, 77, 776-790.

Clavero P, Martin J, Raso JM (1996) Atles Climàtic de Catalunya. Termopluviometria. Institut Cartogràfic de Catalunya, Barcelona.

Connor HE (1971) A naturalized Cortaderia (Gramineae) in California. Madroño, 21, 39-40.

Connor HE, Edgar E (1974) Names and types in Cortaderia stapf (Gramineae). Taxon, 23, 595-605.

D'Antonio CM, Vitousek PM (1992) Biological Invasions by Exotic Grasses, the Grass/Fire Cycle, and Global Change. Annual Review of Ecology and Systematics, 23, 63-87.

Debussche M, Lepart J, Dervieux A (1999) Mediterranean landscape changes: evidence from old postcards. Global Ecology and Biogeography, 8, 3-15.

Grove AT, Rackham O (2001) The Nature of Mediterranean Europe. An Ecological History. Yale Univerity Press, Yale.

Higgins SI, Richardson DM (1998) Pine invasions in the southern hemisphere: modelling interactions between organism, environment and disturbance. Plant Ecology, 135, 79-93.

Higgins SI, Richardson DM, Cowling RM et al. (1999) Predicting the landscape-scale distribution of alien plants and their threat to plant diversity. Conservation Biology, 13, 303-313.

Hobbs RJ (2000) Land-use changes and Invasions. In: Invasive Species in a Changing World (eds Mooney A, Hobbs RJ), pp. 5564. Island Press, Washington, DC.

Le Floc'h E (1991) Invasive plants of the Mediterranean Basin. In: Biogeography of Mediterranean Invasions (eds Groves RH, Di Castri F), pp. 67-80. Cambridge University Press, Cambridge.

Lambrinos JG (2002) The variable invasive success of Cortaderia species in a complex landscape. Ecology, 83, 518-529.

Mack RN, Lonsdale WM (2001) Humans as global plant dispersers: getting more than we bargained for. Bioscience, 51, 95-102.

Mooney HA, Hobbs RJ (2000) Global change and invasive species: where do we go from Here? In: Invasive Species in a Changing World (eds Mooney A, Hobbs RJ), pp. 425-434. Island Press, Washington, DC.

Naveh Z, Vernet JL (1991) The palaeohistory of the mediterranean biota. In: Biogeography of Mediterranean Invasions (eds Groves RH, Di Castri F), pp. 19-32. Cambridge University Press, Cambridge.

Parker IM, Reichard SH (1998) Critical issues in invasion biology for conservation science. In: Conservation Biology for the Coming Decade, 2nd edn (eds Fiedler PL, Kareira PM), pp. 283-305. Chapman \& Hall, London. 
Pons X (2001) MiraMon. Geographic Information System and remote Sensing Software, ISBN 84-931323, pp. 5-7. Centre de Recerca Ecològica i Aplicacions Forestals, Bellaterra.

Pysek P (1998) Alien and native species in Central European urban floras: a quantitative comparison. Journal of Biogeography, 25, 155-163.

Rose S (1997) Influence of suburban edges on invasion of Pittosporum undulatum into the bushland of northern Sydney, Austalia. Austalian Journal of Ecology, 22, 89-99.

Roy DB, Hill MO, Rothery P (1999) Effects of urban land cover on the local species pool in Britain. Ecography, 22, 507-515.

Sala OE, Chapin FS, Armesto JJ et al. (2000) Global biodiversity scenarios for the Year 2100. Science, 287, 1770-1774.

Saurí D, Breton F, Ribas A et al. (2000) Policy and practice. The ecological values of traditional land use in low-lying coastal environments: the example of the Aiguamolls de l'Empordà, Costa Brava. Journal of Environmental Planning and Management, 43, 277-290.
Sobrino E, Sanz-Elorza M, Dana ED et al. (2002) Invasibility of a coastal strip in NE Spain by alien plants. Journal of Vegetation Science, 13, 585-594.

Thornes JB (1996) Introduction. In: Mediterranean Desertification and Land Use (eds Brandt CJ, Thornes JB), pp. 4-11. John Wiley \& Sons, New York.

Thomson AG, Radford GL, Norris DA et al. (1993) Factors affecting the distribution and spread of Rhododendron in North Wales. Journal of Environmental Management, 39, 199212.

Vilà M, Burriel JA, Pino J et al. (2003) Association between Opuntia species invasion and changes in land-cover in the Mediterranean region. Global Change Biology, 9, 1234-1239.

Vilà M, García-Berthou E, Sol D et al. (2001) Survey of the naturalized plants and vertebrates in peninsular Spain. Ecologia Mediterranea, 27, 55-67.

Vitousek PM (1994) Beyond global wariming: ecology and global change. Ecology, 75, 1861-1876. 